Forestry and Grassland Received on: $17 / 12 / 2020$ Accepted on: 11/05/2021

\title{
Gas exchange, chemical composition and productive characteristics of tropical grasses deferred II: cultivars BRS Paiaguás and BRS Piatã
}

Trocas gasosas, características produtivas e composição química de gramíneas tropicais diferidas II: cultivares BRS Paiaguás e BRS Piatã

${ }^{1}$ SANTOS, Francisca Gisele Rodrigues dos https://orcid.org/0000-0003-0276-3426

${ }^{2 *}$ ARAÚJO, Ricardo Alves de https://orcid.org/0000-0001-9696-5680

${ }^{3}$ CÂNDIDO, Magno José Duarte https://orcid.org/ 0000-0003-3573-6053

${ }^{4}$ ROGÉRIO, Marcos Cláudio Pinheiro https://orcid.org/ 0000-0003-3567-5211
${ }^{3}$ COSTA, Clésio dos Santos

https://orcid.org/ 0000-0003-0451-7157

${ }^{5}$ SILVA, Valdson José da

https://orcid.org/ 0000-0001-5650-9648

${ }^{6}$ FURTADO, Rafael Nogueira

https://orcid.org/ 0000-0002-4502-786X

${ }^{4}$ POMPEU, Roberto Cláudio Fernandes Franco

https://orcid.org/0000-0002-4099-3575

${ }^{1}$ Universidade Estadual Vale do Acaraú - UVA, Av. da Universidade, 850, Campus da Betânia Sobral/CE, Brasil

${ }^{2}$ Universidade Estadual do Maranhão - UEMA, Centro de Estudos Superiores de Balsas - CESBA, Balsas/MA, Brasil

${ }^{3}$ Universidade Federal do Ceará - UFC, Av. Mister Hull, 2977 - Bloco 847 - Campus do Pici, Fortaleza/CE, Brasil.

${ }^{4}$ Empresa Brasileira de Pesquisa Agropecuária - EMBRAPA, Centro Nacional de Pesquisa de Caprinos, Sobral, CE, Brasil.

${ }^{5}$ Universidade Federal Rural de Pernambuco - UFRPE, Rua Dom Manuel de Medeiros, s/n, Dois Irmão, Recife/PE, Brasil

${ }^{6}$ Instituto Federal de Educação, Ciência e Tecnologia do Piauí - IFPI, BR 407, s/n, Lagoa dos Canudos, Paulistana, PI, Brasil.

*Mail for correspondence: ricardo_zoo@hotmail.com

\section{ABSTRACT}

This study aimed to evaluate the physiological parameters, the productive characteristics, structural and chemical composition of Urochloa Brizantha cultivars BRS and BRS Piatã submitted to two deferment periods and three using times. The experimental design was randomized complete block design in a factorial scheme $2 \times 2 \times 3$, being two grass cultivars (Paiaguás grass and Piatã grass), two deferment periods (rainy season and dryrainy transition) and three sealing times (40, 80 and 120 days). It was observed that, in the rainy season, the grasses had higher leaf transpiration rate when used for 40 days of deferment $(1.66 \mu \mathrm{mol} \mathrm{m} / \mathrm{s})$. During the rainy season, the Stomatal conductance was 
detected only in the grasses used with shorter seal, with an average of $0.07 \mu \mathrm{mol} \mathrm{m} / \mathrm{s}$. In contrast, in the period of transition, the concentration decreased to $0.02 \mu \mathrm{mol} \mathrm{m} / \mathrm{s}$. In a general way, the BRS Paiaguás presented lower content of NDF. The shorter cycle provided greater biomass production of total forage during the period of rain, approximately 2.78 times more than the same pasture grass deferred during the transition period. Generally, the periods of deferment and moments of use cause effects on structural characteristics of pasture, being that the period of deferment of the transition period and used for 40 and 80 days may be a strategy for keeping animals in critical periods.

Keywords: Forage accumulation, tipping index, leaf photosynthesis rate, Urochloa brizantha.

\section{RESUMO}

Objetivou-se avaliar os parâmetros fisiológicos, as características produtivas, estruturais e composição química da Urochloa Brizantha cultivares BRS Paiaguás e BRS Piatã submetidos a dois períodos de diferimento e três momentos de utilização. Utilizou-se o delineamento de blocos completos casualizados, em esquema fatorial $2 \times 2 \times 3$, sendo duas cultivares de gramíneas (capim-paiaguás e capim- piatã), dois períodos de diferimento (período chuvoso e transição chuvoso-seco) e três tempos de vedação $(40,80$ e 120 dias). Observou-se que, dentro do período chuvoso, as gramíneas tiveram maior taxa de transpiração foliar quando utilizadas aos 40 dias de diferimento $(1,66 \mu \mathrm{mol} \mathrm{m} / 2)$. Neste mesmo período, a condutância estomática foi detectada somente nas gramíneas utilizadas com menor tempo de vedação, apresentando média de $0,07 \mu \mathrm{mol} \mathrm{m} / \mathrm{s}$. Em contrapartida, no período de transição, a concentração diminuiu para $0,02 \mu \mathrm{mol} \mathrm{m} / \mathrm{s}$. De forma geral, a cultivar BRS Paiaguás apresentou menor teor de FDN. O menor tempo de vedação proporcionou maior produção de biomassa de forragem total durante o período da chuva, cerca de 2,78 vezes mais forragem que o mesmo pasto diferido durante o período de transição. De modo geral, ambos os períodos de diferimento e tempos de vedação causam efeitos nas características estruturais da pastagem, sendo que o diferimento no período de transição por um tempo de 40 e 80 dias pode ser uma estratégia para manutenção dos animais em períodos críticos.

Palavras-chave: acúmulo de forragem, índice de tombamento, taxa fotossintética, Urochloa brizantha.

\section{INTRODUCTION}

Pastures represent the main food source of ruminant animals, constituting the basis of livestock support. However, due to the reasons inherent to the phenology of tropical forage plants and adverse climate conditions, forage production becomes seasonal, resulting in the seasonality of both plant and animal production, thus requiring strategies that can minimize such effects (VILELA et al., 2012; SILVA et al., 2016).

Among the management alternatives to balance the statehood of forage production is the deferment of pasture, which consists of selecting an area of the property and sealing it to grazing. In this way, it is possible to reserve the surplus of fodder produced in the water period for use in the dry period (SOUSA et al., 2019; CARVALHO et al., 2017). To do 
so, there is a need to choose grasses that are more tolerant to the sealing period and that have good productivity and quality (SILVA et al., 2016).

According to Silva et al. (2016), the most recommended forage plants for deferment are those with low accumulation of stems and high production of leaf blades, which causes lower reductions in nutritional value over the sealing period, especially most grasses of the genus Urochloa. Moreover, it should be considered that the structural characteristics of deferred pastures are of fundamental importance, because they are determinant both in the dynamics of growth and competition in plant communities, as well as in the influence of ingestive behavior and on the performance of animals and allow evaluating the quality of forage (SANTOS et al., 2018).

Although the deferment ensures the intake of grasses during the months of scarcity, it should be emphasized that these fodders have reduced nutritional value (TEIXEIRA et al., 2011). To reduce this problem, some management practices can be applied, such as the use of a shorter deferment period of pasture and fertilization at the beginning of the deferment period (SANTOS et al., 2013). However, there is a need for more studies about the correct management, besides, of course, different other factors related to the deferment of pasture (NOGUEIRA et al., 2020). Thus, the objective of this work was to evaluate the physiological parameters, structural and productive characteristics, in addition to the chemical composition of grasses of the species Urochloa brizantha, cultivars BRS Paiaguás and BRS Piatã, under two deferment times and three moments of pasture use.

\section{MATERIAL AND METHODS}

The experiment was conducted in the municipality of Sobral, Ceará, Brazil, at Fazenda Três Lagoas $\left(3^{\circ} 45^{\prime} 00.77^{\prime \prime} \mathrm{S}\right.$ and $40^{\circ} 20^{\prime} 38.55^{\prime \prime}$ O), belonging Empresa Brasileira de Pesquisa Agropecuária (EMBRAPA), in Centro de Pesquisa com Caprinos e Ovinos, from march to october 2016. The climate is BSH type, semi-arid hot, with rains between december and may. Rainfall, air humidity, average temperature and wind speed data (Inmet, 2016) are shown in Figure 1. 


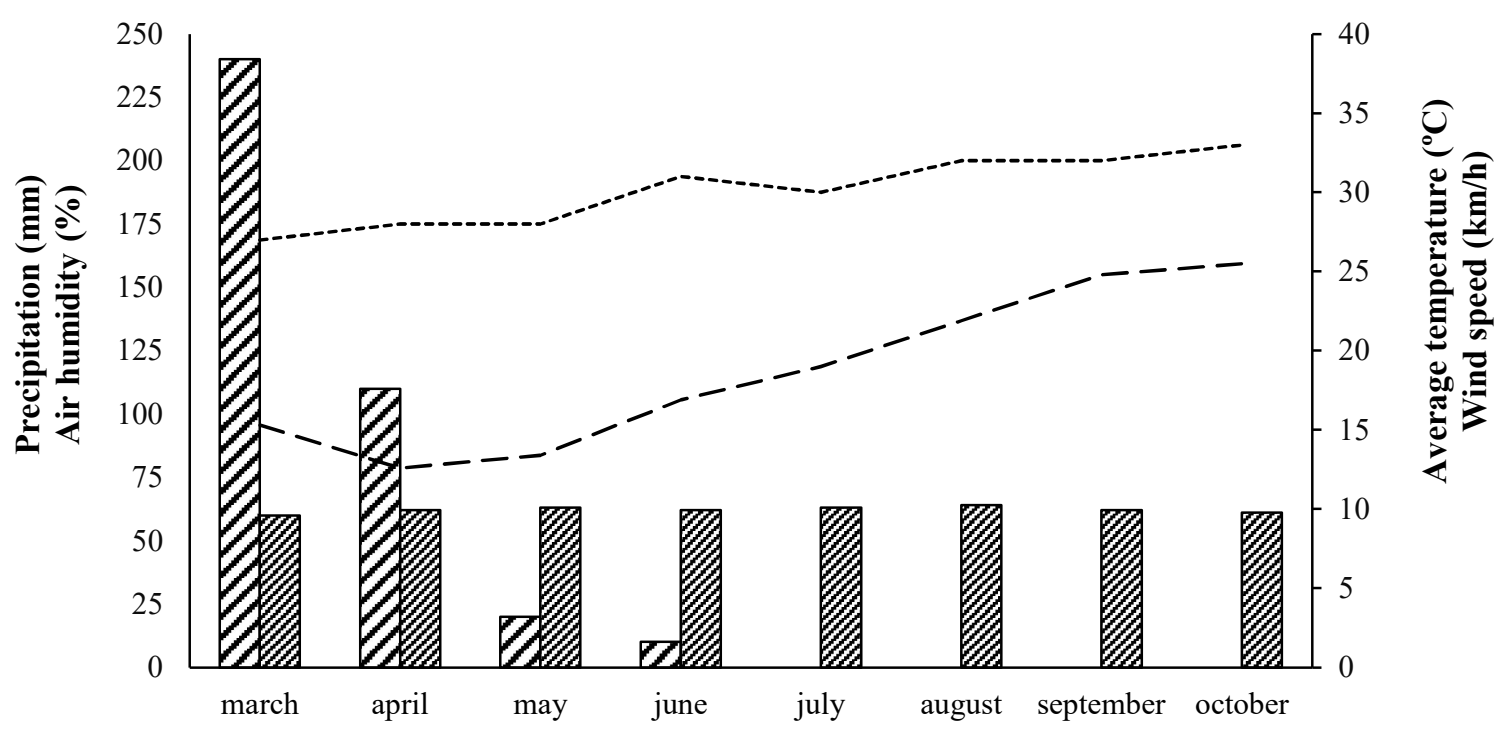

Months

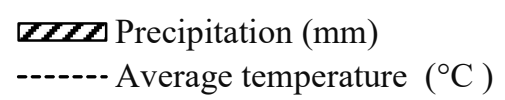

שWZ Air humidity (\%) - - - wind speed $(\mathrm{km} / \mathrm{h})$

Figure 1. Precipitation, air humidity, average temperature and wind speed during the trial period (March to October 2016)

The soil of the experimental area is classified as Chromic Luvissol (SANTOS et al., 2018). The tillage consisted of a crate and two gradations. Before the implementation of the experiment, soil samples were collected to evaluate its fertility, which presented the following chemical characteristics: $\mathrm{pH}$ (in $\mathrm{H}_{2} \mathrm{O}$ ) $=6.75$; Organic matter $\left(\mathrm{g} / \mathrm{dm}^{3}\right)=12.50$; Phosphorus $\left(\mathrm{mg} / \mathrm{dm}^{3}\right)=$ 21.5; Potassium $\left(\mathrm{mg} / \mathrm{dm}^{3}\right)=39$; Calcium $\left(\mathrm{mmolc} / \mathrm{dm}^{3}\right)=44.50 ;$ Magnesium $\left(\mathrm{mmolc} / \mathrm{dm}^{3}\right)=28.50 ; \quad \mathrm{H}+\mathrm{Al}$ $\left(\mathrm{mmolc} / \mathrm{dm}^{3}\right) \backslash \mathrm{aa} 445=16$; Aluminum $\left(\mathrm{mmolc} / \mathrm{dm}^{3}\right)=0 ;$ Sodium $\left(\mathrm{mg} / \mathrm{dm}^{3}\right)=$ 101; Boron $\left(\mathrm{mg} / \mathrm{dm}^{3}\right)=0.21$; Copper $\left(\mathrm{mg} / \mathrm{dm}^{3}\right)=1.30 ;$ Iron $\left(\mathrm{mg} / \mathrm{dm}^{3}\right)=30$; Manganese $\left(\mathrm{mg} / \mathrm{dm}^{3}\right)=24.60 ;$ Zinc $\left(\mathrm{mg} / \mathrm{dm}^{3}\right)=2.35$. After cleaning, the soil was fertilized with phosphorus (15 $\left.\mathrm{mg} / \mathrm{dm}^{3}\right)$ and potassium $\left(10 \mathrm{mg} / \mathrm{dm}^{3}\right)$, base saturation $=48 \%$.
Sowing was performed manually for both cultivars, using a viable pure seed rate equivalent to $6.0 \mathrm{~kg} / \mathrm{ha}$ in grooves with $5 \mathrm{~cm}$ depth and spacing between rows of $40 \mathrm{~cm}$. Fertilization was carried out with phosphorus, potassium and micronutrients, with simple superphosphate $(60 \mathrm{~kg}$ of $\mathrm{P} / \mathrm{ha})$, potassium chloride $(20 \mathrm{~kg}$ of $\mathrm{KCl} / \mathrm{ha})$ and micronutrients $(20 \mathrm{~kg} / \mathrm{ha}$ of FTE BR12) as sources of these nutrients. When soil moisture conditions were favorable, nitrogen fertilization (urea source) was applied in two doses. The first occurred ten days after seedling emergence and the second ten days after the first dose. After complete establishment (32 days after sowing), the plants were submitted to a uniformity cut, with a height of 35 $\mathrm{cm}$ above the soil surface, corresponding to a residual leaf area index (LAIr) equal to 2.0, determined with the aid of the $\mathrm{PAR} / \mathrm{LAI}$ analyzer in agriculture 
DECAGON LP-80 (DECAGON Devices, Inc., Pullman, WashingtonUSA).

The experiment was conducted in a randomized block design, in a factorial scheme $2 \times 2 \times 3$, of Urochloa Brizantha cultivars BRS Paiaguás and BRS Piatã, in two periods of deferment (rainy season and transition) and three times of grassland sealing (40, 80 and 120 days), with four replications. Totaling 48 experimental plots of $20 \mathrm{~m}^{2}$ each $(5 \times 4$ $\mathrm{m})$. For the conditioning of the treatments evaluated, two deferment periods were used, the first in the rainy season, where the pastures were managed undercut simulating a grazing, after 14 days of deferment, while the second deferment period, performed in the transition to drought, the pastures were used after 40 days of established. After the periods of use (rainy and transition period), the pastures were sealed to be evaluated at 40,80 and 120 days after the date of pasture sealing (Figure 2).

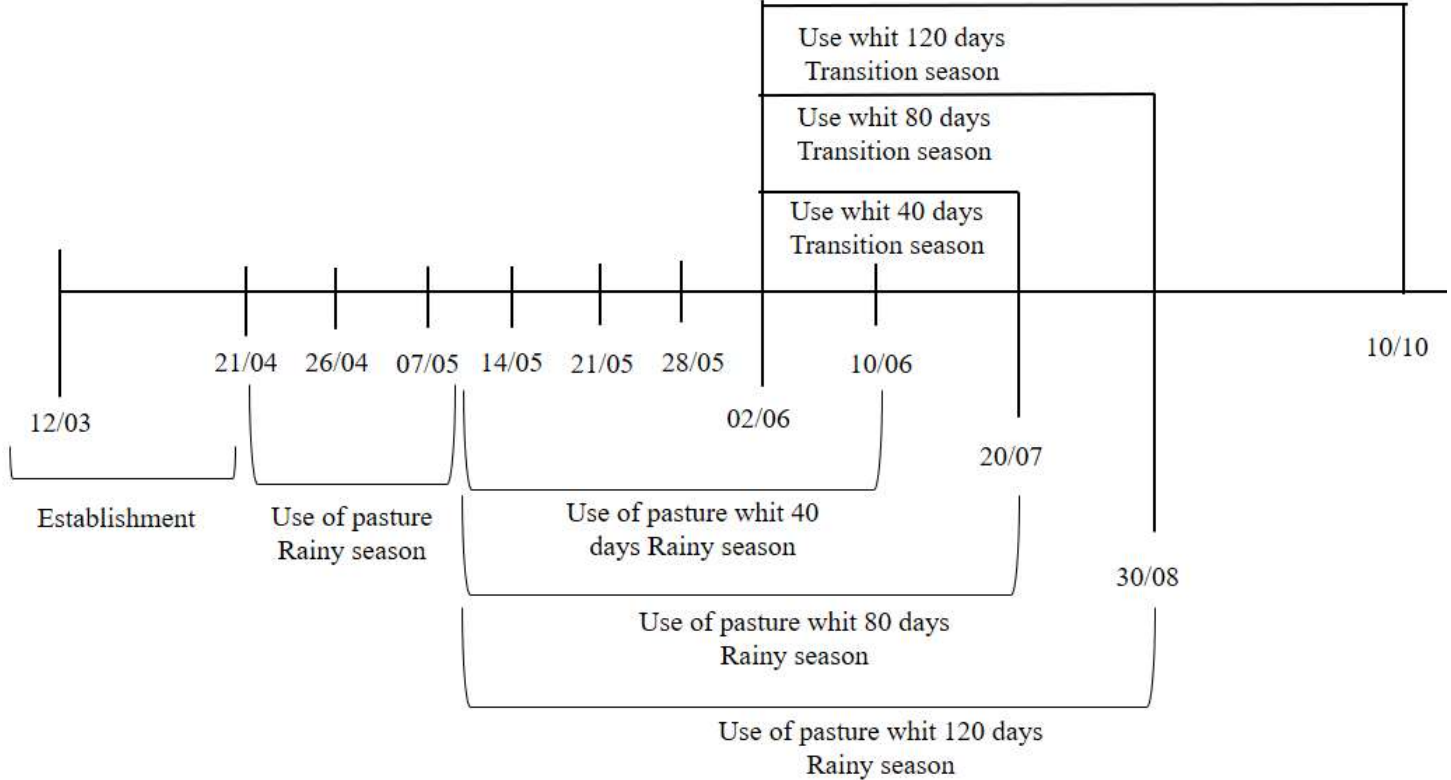

Figure 2. Chronological representation of the experiment

For gas exchange evaluations, the infrared $\mathrm{CO}_{2}$ analyzer, IRGA model LCpro-SD (ADC Bioscientific Ltd. Hoddesdon, Hertfordshire, UK), was used, where at the time of each use after the pasture seal, newly expanded leaves of six tillers were chosen in each experimental unit. The measurements were performed in the median part of the last expanded leaf, always at the times of 9:00 a.m. to 11:00 a.m. The variables, leaf temperature $\left({ }^{\circ} \mathrm{C}\right)$, internal leaf $\mathrm{CO}_{2}$ concentration (ppm), leaf transpiration rate $\left(\mathrm{mol} / \mathrm{m}^{2} / \mathrm{s}\right)$ and leaf photosynthesis rate $\left(\mathrm{mol} / \mathrm{m}^{2} / \mathrm{s}\right)$ were analyzed. The relative chlorophyll index (Unid. SPAD), was measured with the aid of chlorophyll meter (Chlorophyll MeterSPAD-502) for indirect measurement of chlorophyll content in newly expanded leaves.

Gravimetric indices were determined for stem elongation, leaf blade and leaf blade senescence. Therefore, at the end of each period, approximately 10 tillers per sampling unit were collected, taking them to the laboratory and parting them into stems, expanded leaf blades and 
emerging leaf blades. Each of these fractions had its total length recorded, being then submitted to drying in a forced ventilation oven at $55{ }^{\circ} \mathrm{C}$ for 72 hours and weighed, obtaining the weight index per unit length of the emerging leaf blade $(\alpha 1)$, expanded leaf blade $(\alpha 2)$ and stems $(\beta)$. Thus, the rate of production and accumulation of forage was estimated during the growth period, from the elongation rate, and leaf blade senescence, and the rate of stem elongation and the population density of unties, according to the following equations, adapted from Davies (1993): $\mathrm{FPR}=[(\operatorname{LBER} \times \alpha 1)+(\operatorname{SER} \times \beta)] \mathrm{x}$ PDT; FARn $=[($ LBER $\times \alpha 1)+($ SER $\times \beta)$ - (LBSR x $\alpha 2)$ ] x PDT. where:

FPR: Forage production rate $(\mathrm{kg}$ $\mathrm{dm} /$ ha/day); LBER: Leaf blade elongation rate (cm/tiller/day); $\alpha 1$ : Weight index/unit length of emergent leaf blade $(\mathrm{g} / \mathrm{cm})$; SER: Stem elongation rate $(\mathrm{cm} /$ tiller/day); $\beta$ : Weight index per unit of stem length $(\mathrm{g} / \mathrm{cm})$; PDT: Population density of tillers (tillers $/ \mathrm{m}^{2}$ ); FARn: Net forage accumulation rate (kg/ha/day); LBSR: Leaf blade senescence rate $(\mathrm{cm} /$ day); $\alpha 2$ : Weight index/unit length of expanded leaf blade $(\mathrm{g} / \mathrm{cm})$.

At the time of each use after deferment, the samples were randomly collected in $0.50 \times 0.50 \mathrm{~m}$ frames, with manual cuts at ground level. The samples were weighed and separated into leaf blades, stems (stems + sheaths) and senescent material. After fractionation, the samples were placed in a forced air ventilation oven, regulated to $55{ }^{\circ} \mathrm{C}$, for 72 hours and weighed. The biomass of the components was used to calculate the percentage of leaf blades, stems and senescent material. The sum of biomass of the different morphological components was used to determine the total forage biomass ( $\mathrm{kg}$ of DM/ha), dead forage biomass ( $\mathrm{kg} \mathrm{DM} / \mathrm{ha})$, leaf blade/stem. The efficiency of water use ( $\mathrm{kg} \mathrm{DM} / \mathrm{mm}$ ) was estimated by dividing the total forage biomass by the amount of accumulated precipitation $(\mathrm{mm})$ during the sealing period of each deferment.

Canopy height was determined by measuring eight points in each experimental plot, with the aid of a graduated ruler and taking as criterion the distance between the part of the plant located highest in the canopy and the soil level. The tipping index was obtained by dividing the height of the extended plant and the height of the non-extended canopy. The population density of tillers was determined by counting the number of tillers that contained inside the frame.

After pre-drying, the samples of morphological fractions were crushed in knife mills (Wiley mill, Arthur $\mathrm{H}$. Thomas, Philadelphia, PA, USA) with a $1.0 \mathrm{~mm}$ sieve. In the ground samples, the levels of DM (method no. 934.01) and CP (method no. 954.01) were determined according to AOAC (2003). For neutral detergent fiber (NDF) analyses, the samples were treated with thermostable alpha-amylase, without the use of sodium sulphite and corrected for residual ash (MERTENS, 2002), which was analyzed according to Van Soest et al. (1991).

Statistical analyses were performed using the MIXED procedure of the SAS ${ }^{\circledR}$ (EdSAS Inst. Inc., Cary, NC, USA, 2015). The data were submitted to normality (Shapiro-Wilks) and homoscedasticity tests (Levene) and, after the assumptions, were submitted to analysis of variance by $F$ test. The analyses were performed from the following model: Yijkm $=\mu+\propto \mathrm{i}+\beta \mathrm{j}+$ 
$\gamma \mathrm{k}+(\alpha \beta \gamma) \mathrm{ijk}+\delta \mathrm{m}+$ eijkm. Where Yijkm is the dependent variable corresponding to the experimental observation; $\mu$ is the general average; $\alpha \mathrm{i}$ is the fixed effect of cultivars; $\beta \mathrm{j}$ is the fixed effect of the deferment period; $\gamma \mathrm{k}$ is the fixed effect of the moment of use; $(\alpha \beta \gamma)$ ij is the interaction effect between cultivar, period and time of use; $\delta \mathrm{m}$ is the random block effect; and eijk is the random error, assuming a normal distribution. The interaction between the factors was deployed only when significant to $5 \%$ probability. To evaluate the effects of each factor, the means were compared by the Tukey test, at $5 \%$ probability.

\section{RESULTS AND DISCUSSION}

Interaction $(\mathrm{P}<0.05)$ was observed between deferment times and sealing times on leaf transpiration rate, stomatic conductance and photosynthesis rate (Table 1). When unfolding the effects, it was observed that, during the rainy season, the grasses had a higher rate of leaf transpiration when used at 40 days of deferment $\left(1.66 \mu \mathrm{mol} / \mathrm{m}^{2} / \mathrm{s}\right)$. On the other hand, when comparing with the transition period, the grasses used with the same deferment time had a reduction of $77 \%$, which in turn did not differ from the other moments of use in the same period.

Table 1. Unfolding of the interaction between deferment periods and moments of use on gas exchanges of cultivars BRS Paiaguás and BRS Piatã

\begin{tabular}{|c|c|c|c|c|}
\hline \multirow{3}{*}{ Deferment periods } & \multicolumn{3}{|c|}{ Moments of use (days) } & \multirow{3}{*}{$\mathrm{SEM}^{1}$} \\
\hline & 40 & 80 & 120 & \\
\hline & \multicolumn{3}{|c|}{ Leaf transpiration rate $\left(\mu \mathrm{mol} / \mathrm{m}^{2} / \mathrm{s}\right)$} & \\
\hline Rainy & $1.66 \mathrm{Aa}$ & $0.42 \mathrm{Ab}$ & $0.54 \mathrm{Ab}$ & \multirow{2}{*}{0.06} \\
\hline \multirow[t]{2}{*}{ Transition } & $0.39 \mathrm{Ba}$ & $0.53 \mathrm{Aa}$ & $0.53 \mathrm{Aa}$ & \\
\hline & \multicolumn{3}{|c|}{ Stomatic conductance $\left(\mu \mathrm{mol} / \mathrm{m}^{2} / \mathrm{s}\right)$} & \multirow{4}{*}{0.01} \\
\hline Rainy & $0.07 \mathrm{Aa}$ & $0.00 \mathrm{Ab}$ & $0.00 \mathrm{Ab}$ & \\
\hline \multirow[t]{2}{*}{ Transition } & $0.02 \mathrm{Ba}$ & $0.00 \mathrm{Aa}$ & $0.00 \mathrm{Aa}$ & \\
\hline & \multicolumn{3}{|c|}{ Photosynthesis rate $\left(\mu \mathrm{mol} / \mathrm{m}^{2} / \mathrm{s}\right)$} & \\
\hline Rainy & $6.72 \mathrm{Aa}$ & $0.75 \mathrm{Ab}$ & $0.89 \mathrm{Ab}$ & \multirow{2}{*}{0.02} \\
\hline Transition & $0.90 \mathrm{Ba}$ & $0.76 \mathrm{Aa}$ & $0.76 \mathrm{Aa}$ & \\
\hline
\end{tabular}

Averages followed by different lowercase letters in the line and different uppercase letters in the column differ by Tukey test $(\mathrm{P}<0.05) .{ }^{1}$ Standard error mean.

During the rainy season, stomatic conductance was detected only in the grasses used with shorter sealing time, with an average of $0.07 \mu \mathrm{mol} / \mathrm{m}^{2} / \mathrm{s}$. On the other hand, during the transition period, the concentration decreased to $0.02 \mu \mathrm{mol} / \mathrm{m}^{2} / \mathrm{s}$. In the other times of use, in both evaluation periods, the stomatic conductance was equal to zero. As well as the leaf transpiration rate, the shorter deferment time provided a higher photosynthetic rate $\left(6.72 \mu \mathrm{mol} / \mathrm{m}^{2} / \mathrm{s}\right)$, presenting $5.82 \mu \mathrm{mol} / \mathrm{m}^{2} / \mathrm{s}$ at the same deferment time, but in the transition period. The triple relationship between the highest rates of leaf transpiration and at the same time, higher leaf photosynthetic rate observed in deferred 
pastures with 40 days during the rainy season is related to the intense photosynthetic capacity of these plants in these conditions (MONTEIRO et al., 2014; TAIZ \& ZEIGER, 2017).

There was a triple interaction $(\mathrm{P}<0.05)$ on the relative chlorophyll index of both cultivars (Table 2). A lower chlorophyll content was observed in BRS Piatã during the transition period, when used after 120 days of deferment (12.85 Unit SPAD). On the other hand, the highest Index was observed in the cultivar BRS Paiaguás when used after 40 days of deferment in the rainy season (35 Unit SPAD), which in turn did not differ from the other sealing times in the same period, as well as from the transition period and the rainy season of BRS Piatã, when used after 40 days of deferment (29.95 Unit SPAD). It is worth mentioning that this Index can help the management of pastures, allowing an instant estimate of protein content and correlating with the nutritional value of forage grasses (SOUZA et al., 2016), since the chlorophylls are found in the leaf mesophyll, the tissue most active photosynthetic (AMARAL et al., 2020) and consequently represent better agronomic performance of the plant (MELO et al., 2015), which in turn may be related to the protein content of the plants (TAZ \& ZEIGER, 2017).

Table 2. Unfolding of the interaction between cultivars, deferment periods and moments of use on chlorophyll index of cultivars BRS Paiaguás and BRS Piatã

\begin{tabular}{llllll}
\hline \multirow{2}{*}{ Cultivars } & & \multicolumn{3}{l}{ Moments of use (days) } & \multirow{2}{*}{ SEM $^{1}$} \\
\cline { 3 - 5 } BRS Paiaguás & Deferment periods & 40 & 80 & 120 & \\
& Rainy & $35.60 \mathrm{Aa}$ & $29.50 \mathrm{Aa}$ & $32.80 \mathrm{Aa}$ & \\
\cline { 2 - 6 } BRS Piatã & Transition & $33.70 \mathrm{Aa}$ & $14.85 \mathrm{Bb}$ & $16.10 \mathrm{Ab}$ & 0.90 \\
& Rainy & $29.95 \mathrm{Aa}$ & $33.55 \mathrm{Aa}$ & $14.45 \mathrm{Bb}$ & \\
& Transition & $19.15 \mathrm{Ba}$ & $14.75 \mathrm{Ba}$ & $12.85 \mathrm{Bb}$ & \\
\hline \multirow{2}{*}{ Avera }
\end{tabular}

Averages followed by different lowercase letters in the line and different uppercase letters in the column differ by Tukey test $(\mathrm{P}<0.05) .{ }^{1}$ Standard error mean.

Both cultivars had the same pasture height during the transition period, which in turn were smaller than pastures during the rainy season, $43 \mathrm{~cm}$ to cultivar BRS Paiaguás and $39.20 \mathrm{~cm}$ to Piatã (Table 3). Regarding the population density of tillers, a similar result was observed, where the lowest amount of tillers was accounted for during the transition period, 440.70 tillers $/ \mathrm{m}^{2}$ for
BRS Paiaguás and 301.00 tillers $/ \mathrm{m}^{2}$ for BRS Piatã. On the other hand, during the rainy season there were higher densities, 42.60 and 20.70 tillers $/ \mathrm{m}^{2}$ Paiaguás and Piatã, respectively. The tipping index was higher during the transition period for the cultivar BRS Paiaguás (1.76), and in both periods higher than BRS Piatã, which in turn did not differ between periods. 
Table 3. Unfolding of the interaction between cultivars and Deferment periods on pasture height, stock density of byes and tipping index of cultivars BRS Paiaguás and BRS Piatã

\begin{tabular}{|c|c|c|c|}
\hline \multirow{3}{*}{ Cultivars } & \multicolumn{2}{|c|}{ Deferment periods } & \multirow{3}{*}{ SEM } \\
\hline & Rainy & Transition & \\
\hline & \multicolumn{2}{|c|}{ Pasture height $(\mathrm{cm})$} & \\
\hline BRS Paiaguás & $43.00 \mathrm{Aa}$ & $28.80 \mathrm{Ab}$ & \multirow{3}{*}{0.76} \\
\hline \multirow[t]{2}{*}{ BRS Piatã } & $39.20 \mathrm{Ba}$ & $30.00 \mathrm{Ab}$ & \\
\hline & \multicolumn{2}{|c|}{ Population density of tillers (tillers $/ \mathrm{m}^{2}$ ) } & \\
\hline \multirow{3}{*}{$\begin{array}{l}\text { BRS Paiaguás } \\
\text { BRS Piatã }\end{array}$} & $483.30 \mathrm{Aa}$ & $440.70 \mathrm{Ab}$ & \multirow{3}{*}{0.65} \\
\hline & $321.70 \mathrm{Ba}$ & $301.00 \mathrm{Bb}$ & \\
\hline & \multicolumn{2}{|c|}{ Tipping index } & \\
\hline BRS Paiaguás & $1.54 \mathrm{Ab}$ & $1.76 \mathrm{Aa}$ & \multirow{2}{*}{0.86} \\
\hline BRS Piatã & $1.37 \mathrm{Ba}$ & $1.21 \mathrm{Ba}$ & \\
\hline
\end{tabular}

Averages followed by different lowercase letters in the line and different uppercase letters in the column differ by Tukey test $(\mathrm{P}<0.05) .{ }^{1}$ Standard error mean.

According to Santos et al. (2013), the stem of cultivars of the species Urochloa Brizantha are thin and flexible, which allows the tipping of these plants in old age. Thus, to reduce the tipping rate of a deferred pasture, different management strategies can be used, which in addition to reducing the deferment period also reduce the forage losses that are associated with this practice (SOUZA et al., 2016). A similar response was observed when comparing the ages of use for BRS Paiaguás grass, where the deferment period occurred in the rainy season provided a higher rate of tipping in the pastures used at 120 days after deferment, a result of the advanced age of the grasses.

Santos et al. (2013) classified deferred pastures of Urochloa Brizantha as to the level of tipping of plants, where plants with tipping index less than or equal to 1.5 are classified as normal, without bedridden; plants with tipping index between 1.5 and 2.0, are considered moderately layered and plants with tipping index greater than or equal to 2.0 are considered very layered. Therefore, when the cultivar BRS Piatã was evaluated, in both deferment periods and moments of use, it can be considered without bed, while the cultivar BRS Paiaguás, when evaluated in the transition period, can be classified as moderately bedridden, with a general average tipping index equal to 1.77.

Thus, it is possible to relate the highest tipping index (TI) observed in the sealed pastures in the transition period with the lowest population density of tillers. In addition, wind speed (Figure 1) may have contributed to aggravate this effect, given that winds with a speed above 10 $\mathrm{km} / \mathrm{h}$ can cause mechanical damage in forage grasses such as those of the species Urochloa Brizantha, causing stem breakage and leaf detachment, contributing to the loss of accumulated biomass (PEREIRA et al., 2002). Pastures that have a high tipping rate end up resulting in a reduction in skinning, due to the higher coefficient of luminous extinction, caused by the condition of greater mutual shading, accelerating the senescence process of green leaves and, compromising consequently on the 
nutritive value of the pasture. In addition, the elevation of the stems compromises the structure of the pasture by the elevation of the apical meristem with the consequent decapitation by defoliation or trampling of the animals, also compromising the voluntary consumption of DM by the grazing animal due to the thickening of the secondary plant cell wall, with the accumulation of lignin and less digestible structural carbohydrates (POMPEU et al., 2009). Therefore, the importance of the adoption of management practices aimed at its control should be highlighted.

At all times of use, the cultivar BRS Paiaguás presented higher height, which decreased with increasing deferment times, with values of $43.50,33.90$ and $30.40 \mathrm{~cm}$ for the 40,80 and 120 days of deferment, respectively (Table 4). The cultivar BRS Piatã decreased the height only in the longest deferment time (26.70 $\mathrm{cm})$. In relation to the population density of tillers, there was an intense reduction with the increase of the deferment time in both grasses, resulting from the higher tipping index, which can bring as a consequence, the impairment of the pasture's perpetuity, culminating in the degradation process, resulting from decapitation by defoliation or trampling of animals. The cultivar BRS Piatã presented higher density of tillers when compared to BRS Paiaguás at 40 and 80 days of deferment (532.50 and 410.50 tillers $/ \mathrm{m}^{2}$, respectively).

Table 4. Unfolding of the interaction between cultivars and moments of use on pasture height and population density of tillers BRS paiaguás and BRS Piatã

\begin{tabular}{|c|c|c|c|c|}
\hline \multirow{3}{*}{ Cultivars } & \multicolumn{3}{|c|}{ Moments of use (days) } & \multirow{3}{*}{$\mathrm{SEM}^{1}$} \\
\hline & 40 & 80 & 120 & \\
\hline & \multicolumn{3}{|c|}{ Pasture height $(\mathrm{cm})$} & \\
\hline BRS Paiaguás & $43.50 \mathrm{Aa}$ & $33.90 \mathrm{Ab}$ & $30.40 \mathrm{Ac}$ & \multirow{3}{*}{1.08} \\
\hline \multirow[t]{2}{*}{ BRS Piatã } & $39.80 \mathrm{Ba}$ & $37.40 \mathrm{Ba}$ & $26.70 \mathrm{Bb}$ & \\
\hline & \multicolumn{3}{|c|}{ Population density of tillers (tillers $/ \mathrm{m}^{2}$ ) } & \\
\hline BRS Paiaguás & $500.50 \mathrm{Ba}$ & $360.50 \mathrm{Bb}$ & $251.00 \mathrm{Ac}$ & \multirow{2}{*}{2.98} \\
\hline BRS Piatã & $532.50 \mathrm{Aa}$ & $410.50 \mathrm{Ab}$ & $254.00 \mathrm{Ac}$ & \\
\hline
\end{tabular}

Averages followed by different lowercase letters in the line and different uppercase letters in the column differ by Tukey test $(\mathrm{P}<0.05) .{ }^{1}$ Standard error mean.

Interaction $(\mathrm{P}<0.05)$ (deferment periods $\mathrm{x}$ moments of use) was observed on the biomass of total forage, green leaf blade and green stems (Table 5). When comparing the periods, it was observed that only in the shortest deferment time there was a difference between the total forage biomass, where the rainy season provided a greater amount of total forage $(5,667.15 \mathrm{~kg}$ of DM/ha), about 3,631.90 $\mathrm{kg}$ of forage more than the transition period. 
Table 5. Unfolding of the interaction between the deferment periods and moments of use on forage biomass of the cultivars BRS Paiaguás and BRS Piatã

\begin{tabular}{|c|c|c|c|c|}
\hline \multirow{3}{*}{ Deferment periods } & \multicolumn{3}{|c|}{ Moments of use (days) } & \multirow{3}{*}{$\mathrm{SEM}^{1}$} \\
\hline & 40 & 80 & 120 & \\
\hline & \multicolumn{3}{|c|}{ Total forage biomass (kg DM/ha) } & \\
\hline Rainy & $5,667.15 \mathrm{Aa}$ & $3,367.71 \mathrm{Ab}$ & $2,344.39$ Ac & \multirow{3}{*}{76.94} \\
\hline \multirow[t]{2}{*}{ Transition } & $2,035.25 \mathrm{Ba}$ & $2,468.05 \mathrm{Aa}$ & $1,651.88 \mathrm{Aa}$ & \\
\hline & \multicolumn{3}{|c|}{ Green leaf blade biomass (kg DM/ha) } & \\
\hline Rainy & $2,900.60 \mathrm{Aa}$ & $945.30 \mathrm{Ab}$ & $835.50 \mathrm{Ab}$ & \multirow{3}{*}{33.17} \\
\hline \multirow[t]{2}{*}{ Transition } & $461.80 \mathrm{Ba}$ & $675.30 \mathrm{Ba}$ & $320.00 \mathrm{Ba}$ & \\
\hline & \multicolumn{3}{|c|}{ Green stem biomass (kg DM/ha) } & \\
\hline Rainy & $1,939.40 \mathrm{Aa}$ & $1,336.00 \mathrm{Ab}$ & $1,032.90 \mathrm{Ab}$ & \multirow{2}{*}{38.65} \\
\hline Transition & $853.10 \mathrm{Ba}$ & $1,297.90 \mathrm{Aa}$ & $932.20 \mathrm{Aa}$ & \\
\hline
\end{tabular}

Averages followed by different lowercase letters in the line and different uppercase letters in the column differ by Tukey test $(\mathrm{P}<0.05) .{ }^{1}$ Standard error mean.

The effect of the periods was more expressive in the biomass of green leaf blades, and when comparing both periods, it was observed that in the rainy season the amount of green leaves was much higher than the transition period, about $2,438.80,270$ and $515.50 \mathrm{~kg}$ more for the deferment times of 40, 80 and 120 days, respectively. However, in the period there was no difference between the different moments of deferment use during the transition period and, in the rainy season, the two greatest deferment times did not differ from each other. Regarding green stem biomass, a behavior similar to the production of green leaf blades was observed, with higher value observed during the rainy season in the shortest deferment time $(1,939.40 \mathrm{~kg} \mathrm{DM} / \mathrm{ha})$, about 2.27 times more than in the transition period, which, in turn, was similar to the two deferment times.

In general, the shorter sealing time provided higher total forage biomass (Table 5) during the rainy season, about 2.78 times more forage compared to that produced in the transition period. Moreover, only during the transition period did the pastures deferred for longer presented lower relative chlorophyll indices (Table 1), and this reduction is related to stomatic closure (MONTEIRO et al., 2014), because the low stomatic conductance observed during the transition period, with values of zero in highest deferment times, providing a significant reduction in leaf photosynthesis rate (SANTOS et al., 2013) and water loss by transpiration (MARANHÃO et al., 2019), causing a reduction in cell division and, consequently, lower dry matter production (TAIZ \& ZEIGER, 2017).

The cultivar BRS Paiaguás presented lower NDF (56.71\%) when used with the shortest deferment time, and in both cultivars the NDF content increased with the postponement of time of use of deferred pastures (Figure 3). The lowest NDF content observed in the cultivar BRS Paiaguás during the shortest deferment time was expected, considering that high moisture content is observed in younger plants (ARAÚJO et al., 2016), to the detriment of the increase in the deferment period (COSTA et al., 2017). 


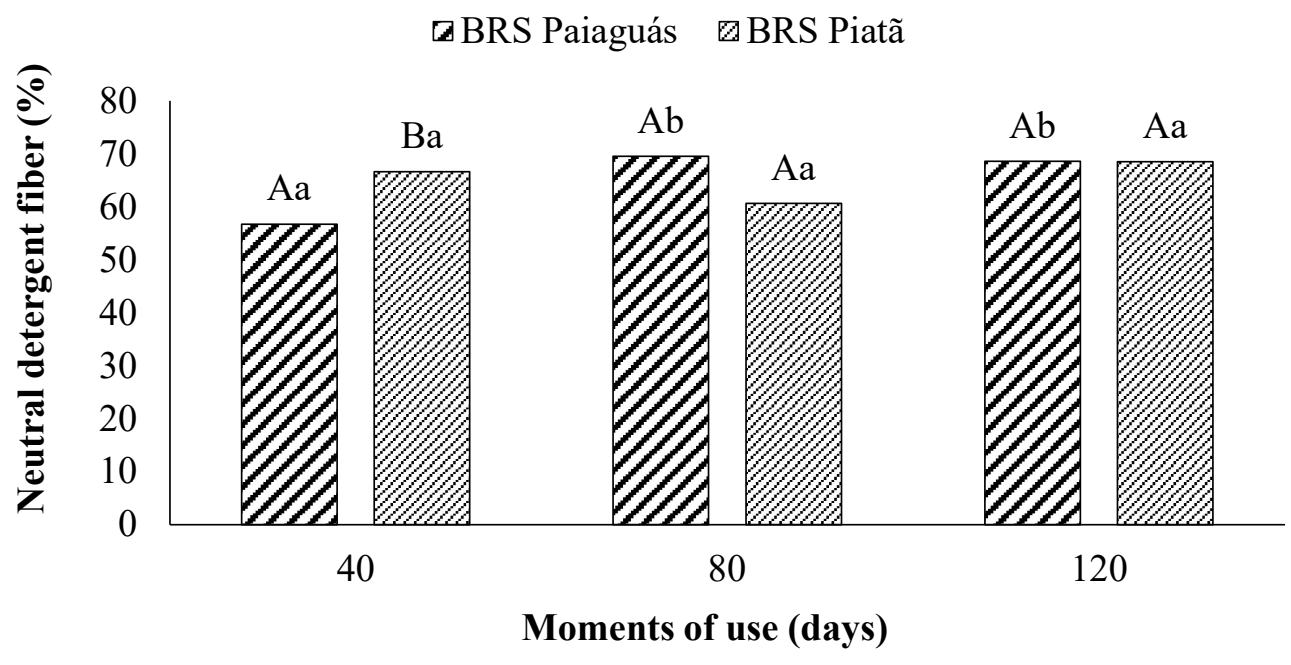

Figure 3. Unfolding of the interaction between cultivars and moments of use on the neutral detergent fiber content of the entire deferred pasture plant of BRS paiaguás and BRS Piatã cultivars

The longer deferment times, in addition to decreasing internal humidity over time, favor stiff cell stiffness, which considerably increases neutral detergent fiber content. These results are justified due to the lower increase in cell wall components during this period and significantly interfere in digestibility, such as lower leaf/stem ratio. It is worth mentioning the importance of the deferment technique for regions with low forage availability, and it should be emphasized that the use of different times of use is a strategy that should be well planned in order to scale the distribution of forage biomass over the dry period.

There was an interaction between deferment times and ages of use on the $\mathrm{CP}$ content of whole plants, where the highest CP contents, both in the rainy or transition periods, were observed in the pastures used at 40 and 80 days after the beginning of deferment (Figure 4). 


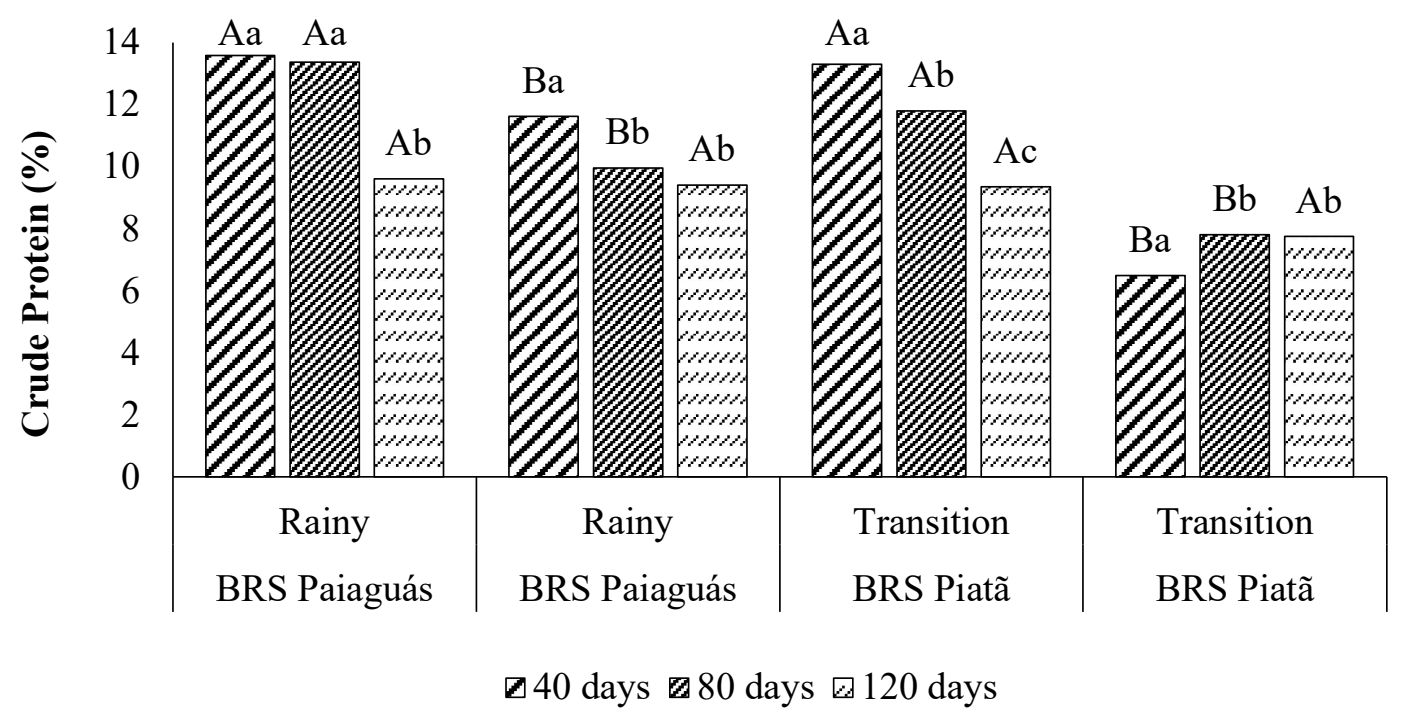

Figure 4. Unfolding of the interaction between cultivars and moments of use on the crude protein content of the entire deferred pasture plant of BRS paiaguás and BRS Piatã cultivars. Lowercase letters compared the moments of use within each period and uppercase letters compared to the same cultivar in a distinct period

The lowest $\mathrm{CP}$ values were found during the transition period, and remained constant, with levels higher than $7 \%$. During the transition period, the cultivar BRS Paiaguás, although it presented the CP content lower than BRS Piatã, presented the minimum $\mathrm{CP}$ content required to meet the nitrogen compounds requirements for the correct functioning of the ruminal microbiota of ruminants at a normal pass-through rate (LAZARINI et al., 2009), which is $7 \%$ of DM. The deferment of the cultivars BRS Piatã and BRS Paiaguás provides higher forage production in the rainy season, highlighting higher production and nutritional value at 40 days after the beginning of deferment. In general, deferment times and moments of use promote effects on the structural characteristics of pastures, and deferment in the transition period and use at 40 and 80 days can be strategic for the maintenance of animals in critical periods.

\section{ACKNOWLEDGMENTS}

The authors are grateful to the Coordenação de aperfeiçoamento de Pessoal do Nível Superior (CAPES) for financing the project and for postgraduate scholarships; to Embrapa Caprinos e Ovinos for all the technical and installation/infrastructure support.

\section{REFERENCES}

AMARAL, A. G.; FRANÇA, A. F. S.; LIMA, M. L. M.; LOBO, U. G. M.; CAIXÊTA, K. O.; SOUSA, L. L. J. M. P.; LOPES, T. A.; BRANDÃO, B. M.; SILVA, L. P. Effect of different doses of nitrogen fertilization on the chlorophyll content, the periling dynamics and morphological composition in millet cultivars in the Savannah. Brazilian Journal of Development. v. 6, p. 21643 21659, 2020. 
ARAÚJO, R. A.; RODRIGUES, R. C.; COSTA, C. S.; SANTOS, F. N. S.; COSTA, F. O.; LIMA, A. J. T.; SILVA, I. R.; RODRIGUES, M. M. Composição químico-bromatológica

degradabilidade in situ de capimMarandu em sistemas silvipastoris formados por babaçu e em monocultivo.

Revista Brasileira de Saúde e Produção Animal. v. 17, p. 401-412, 2016.

ASSOCIATION OF ANALYTICAL CHEMISTS-AOAC, 2003. Official Methods of Analysis, 17th 2nd rev. ed. Association of Analytical Chemists-

AOAC, Gaithersburg, M. D, p. 1094.

CARVALHO, R. M.; ALVES, L. C.; RODRIGUES, P. H. M.; SOUZA, W. D.; ÁVILA, A. B.; SANTOS MER. Acúmulo de forragem e estrutura do dossel de capim-marandu diferido e adubado com nitrogênio. Boletim Indústria Animal. v. 74, p. 1-8, 2017.

COSTA, C. S.; RODRIGUES, R. C.; ARAÚJO, R. A.; CÂNDIDO, M. J. D.; SANTOS, F. N. S.; RODRIGUES, M. M.; COSTA, F. O.; SILVA, I. R.; ALVES, A. A.; LIMA, N. M. Agronomic and nutritional characteristics of Massai grass subjected to deferred grazing and nitrogen fertilization. Semina Ciências Agrárias. v. 38, p. 1617-1624, 2017.

DAVIES, A. Tissue turnover in the swards. In: DAVIES, A. et al. (E E.). Sward measurement handbook. ed. Reading: British Grassland Society, p.183 216, 1993.

INMET - INSTITUTO NACIONAL DE METEOROLOGIA. Disponível em: http://www.inmet.gov.br. Acesso em: 10/03/2020.

LAZZARINI, I.; DETMANN, E.; SAMPAIO, C. B.; PAULINO, M. F.; VALADARES FILHO, S. C.; SOUZA, M. A.; OLIVEIRA, S. A. Dinâmicas de trânsito e degradação da fibra em detergente neutro em bovinos alimentados com forragem tropical de baixa qualidade e compostos nitrogenados. Arquivo Brasileiro de Medicina Veterinária e Zootecnia. v. 61, p. 635-647, 2009.

MARANHÃO, S. R.; POMPEU, R. C. F. F.; SOUZA, H. A.; ARAÚJO, R. A.; FONTINELE, R. G.; CÂNDIDO, M. J. D. Morphophysiology of buffel grass grown under different water supplies in the dry and dry-rainy seasons. Revista Brasileira de Engenharia Agricola e Ambiental. v. 23, p. 566-571, 2019.

MELO, N. C.; FERNANDES, A. R.; GALVÃO, J. R. Crescimento e eficiência nutricional do nitrogênio em cultivares de milheto forrageiro na Amazônia. Revista Caatinga. v. 28, p. 68-78, 2015.

MERTENS, D. R. Gravimetric determination of amylase-treated neutral detergent fiber in feeds with refluxing in beakers or crucibles: collaborative study. Journal of AOAC International. V. 85, p. 1217-1240, 2002.

MONTEIRO, J. G.; CRUZ, F. J. R.; NARDIN, M. B.; SANTOS, D. M. M. Crescimento e conteúdo de prolina em plântulas de guandu submetidas a estresse osmótico e à putrescina exógena. Pesquisa Agropecuária Brasileira. v. 49, p. 18-25, 2014. 
NOGUEIRA, H. C. R.; SANTOS, M. E. R.; CARVALHO, B. H. R.; CARVALHO, A. N.; VASCONCELOS, K. A.; ROCHA, G. O. Initial height and nitrogen fertilization on deferred pastures of marandu palisadegrass. Semina Ciências Agrárias. v. 41, p. 959-970, 2020.

POMPEU, R. C. F. F.; CÂNDIDO, M. J. D.; NEIVA, J. N. M.; ROGÉRIO, M. C. P.; BENEVIDES, Y. I.; OLIVEIRA, B. C. M. Fluxo de biomassa em capimtanzânia sob lotação rotativa com quatro níveis de suplementação concentrada. Revista Brasileira de Zootecnia. v. 38, p. 809-817, 2009.

SANTOS, H. G.; JACOMINE, P. K. T.; ANJOS, L. H. C.; OLIVEIRA, V. A.; OLIVEIRA, J. B.; COELHO, M. R.; LUMBRERAS, J. F.; CUNHA, T. J. F. Sistema Brasileiro de Classificação de Solos. 5. ed. revisada e ampliada. Brasília: Embrapa, 306p, 2018.

SANTOS, M. E. R.; AVILA, A. B.; CARVALHO, A. N.; ROCHA, G. O.; CLEEF, F. S. V.; SEGATTO, B. N.; VASCONCELOS, K. A.; PEREIRA, R. $S$. Marandu palisadegrass management strategies at the beginning of the deferment period and effects on tillering. Semina Ciências Agrárias. v. 39, p. 16617-1626, 2018.

SANTOS, P. M.; CRUZ, P. G.; ARAUJO, L. C.; PEZZOPANE, J. R. M.; VALLE, C. B.; PEZZOPANE, C. G. Response mechanisms of Brachiaria brizantha cultivars to water deficit stress. Revista Brasileira de Zootecnia. v. 42, p. 767-773, 2013.
SILVA, G. M.; SILVA, F. F.; VIANA, P. T.; RODRIGUES, E. S. O.; MOREIRA, C. N.; MENESES, M. A.; ABREU JR, J. S.; RUFINO, C. A.; BARRETO, L. S. Avaliação de forrageiras tropicais: Revisão. Publicações em Medicina Veterinária e Zootecnia. v. 10, p. 190-196, 2016.

SOUSA, B. M. L.; SANTOS, M. E. R.; AMORIM, P. L.; SILVEIRA, M. C. T.; ROCHA, G. O.; CARVALHO, A. N. Effect of nitrogen fertilization on structure and tillering dynamics of Piata palisade grass during the deferment period. Semina: Ciências Agrárias. 40, 249-258, 2019.

SOUSA, B. M. L.; VILELA, H. H.; SANTOS, A. L.; SANTOS, M. E. R.; NASCIMENTO JUNIOR, D.; ASSIS, C. Z.; FARIA, B. D.; ROCHA, G. O. Piata palisadegrass deferred in the fall: effects of initial height and nitrogen in the sward structure. Revista Brasileira de Zootecnia. v. 41, p. 1134-1139, 2012.

SOUZA, I. A.; RIBEIRO, K. G.; ROCHA, W. W.; ARAÚJO, S. A. C.; PEREIRA, O. G.; CECON, P. R. Forage mass, chemical composition and leaf chlorophyll index of signal grass and organic matter in soil under increasing levels of nitrogen. Semina Ciências Agrárias. v. 37, p. 1505-1514, 2016.

TAIZ, L. \& ZEIGER, E. Fisiologia vegetal. $6^{\circ}$ ed. Porto Alegre: Artmed. 722 p, 2017.

TEIXEIRA, F. A.; BONOMO, P.; PIRES, A. J. V. P.; SILVA, F. F. S.; FRIES, D. D.; HORA, D. S. Produção anual e qualidade de pastagem de Brachiaria decumbens diferida e 
estratégias de adubação nitrogenada. Acta Scientiarum. Animal Sciences. v. 33, p. 241-248, 2011.

VAN SOEST, P. J.; ROBERTSON, J. B.; LEWIS, B.A. Methods for dietary fibre, neutral detergent fibre and nonstarch polysaccharides in relation to animal nutrition. Journal of Dairy Science. v. 74, p. 3583-3597, 1991.

VILELA, H. H.; SOUSA, B. M. L.; SANTOS, M. E. R.; SANTOS, A. L.; ASSIS, C. Z.; ROCHA, G. O.; FARIA, B. D.; NASCIMENTO JR D. Forage mass and structure of piata grass deferred at different heights and variable periods.

Revista Brasileira de Zootecnia. v. 41, p. 1625-1631, 2012. 